Lovro Badžim, dipl. iur., LL.M. (Penn State Law) ${ }^{1}$

Karla Gea Marcan, mag. iur. ${ }^{2}$

\title{
JURISDIKCIJSKI PRIGOVORI U PRAKSI ARBITRAŽNOG SUDA ZA SPORT
}

\author{
UDK: 796/799:347 \\ DOI: $10.31141 / z r p f s .2020 .57 .136 .399$ \\ Pregledni znanstveni rad \\ Primljeno: 15. prosinca 2019.
}

\begin{abstract}
Ovaj radi bavi se raznim aspektima ugovora kojima stranke ugovaraju nadležnost Arbitražnog suda za sport za odlučivanje u njihovoj pravnoj stvari, kao i pojavnim oblicima arbitražnih ugovora - kako je propisano, kakav je stav u svojim odlukama zauzeo CAS i kako se o valjanosti takvih ugovora izjasnio Švicarski federalni sud u nekoliko svojih najrelevantnijih odluka. Namjera ovog rada jest ukazati na probleme s kojima se stranke pro futuro mogu susresti, uvođenjem subjektivnih interpretativnih kategorija (od strane tribunala) kao elemenata u strogo formalni zakonski akt, te ponuditi određene alternative nekim postupovnim principima ustanovljenima kroz praksu Švicarskog federalnog suda.
\end{abstract}

Ključne riječi: $C A S$, praksa, sud, sport, sportsko pravo

\section{UVOD}

Nadležnost u sportskoj arbitraži pred Arbitražnim sudom za sport (dalje: CAS) ima određene specifičnosti u odnosu na tradicionalnu trgovačku arbitražu. Ponajprije, člankom S20 Zakonika Arbitražnog suda za sport od 1. siječnja 2019. ${ }^{3}$ (dalje: CAS Zakonik) propisane su tri vrste postupka: redovni postupak, postupak u antidopinškim predmetima i žalbeni postupak. Osim navedenoga, posebnost je

1 Lovro Badžim, arbitar na Arbitražnom sudu za sport (CAS) i Arbitražnom sudu Hrvatskog nogometnog saveza, te odvjetnik u Odvjetničkom društvu Grahovac, Horvat, Žaper d.o.o., Zagreb.

2 Karla Gea Marcan, odvjetnička vježbenica u Odvjetničkom društvu Grahovac, Horvat, Žaper d.o.o., Zagreb.

3 ,a. Odjel za redovnu arbitražu čine vijeća čija je odgovornost rješavanje sporova u redovnom postupku i posredovanjem svog predsjednika ili njegovog/njezinog zamjenika obavljanje svih drugih funkcija u vezi s učinkovitim vođenjem postupka sukladno procesnim pravilima (čl. R27 i dr.); b. Odjel za borbu protiv dopinga čine vijeća čija je nadležnost rješavanje sporova koji se odnose na predmete vezane za doping kao prvostupanjsko tijelo ili kao jednostupanjsko tijelo, te posredovanjem svog predsjednika ili njegovog/njezinog zamjenika obavljanje svih drugih funkcija u vezi s brzim i učinkovitim vođenjem postupka u skladu s procesnim pravilima (čl. A1 i dr.); c. Žalbeni odjel za arbitražu čine vijeća čija je odgovornost rješavanje sporova u vezi s odlukama saveza, udruga ili drugih tijela koji se odnose na sport u mjeri u kojoj to predviđaju statuti ili propisi navedenih sportskih tijela ili poseban sporazum. Također, Žalbeni odjel za arbitražu posredovanjem svog predsjednika ili njegovog/njezinog zamjenika obavlja i sve druge funkcije u vezi s brzim i učinkovitim vođenjem postupka u skladu s procesnim pravilima (članci R27 i dr.)“. 
sportske arbitraže činjenica da arbitražni ugovor, kojim je ugovorena nadležnost CAS-a, često bude uključen u Statute i Pravilnike sportskih organizacija, slijedom čega nisu uvijek jasno utvrđene formalne pretpostavke valjanosti arbitražnog ugovora i pitanje pristanka na arbitražu, posebice u slučajevima gdje je arbitražna klauzula sadržana u pristupnicama za velike sportske događaje.

Dakle, brojne su posebnosti sportskih arbitražnih ugovora u kojima je ugovorena nadležnost CAS-a, no u ovom ćemo radu primarno nastojati odgovoriti na pitanje valjanosti arbitražnih klauzula, izložiti problematiku referentnih arbitražnih klauzula, ukazati na opseg i vrste sporova koje takve klauzule obuhvaćaju, te razvoj prakse kako CAS-a, tako i Švicarskog federalnog suda u pogledu pretpostavki za valjanost arbitražnih ugovora. U zaključku, autor će nastojati detektirati postoji li bilo kakav problem kod ugovora kojima je za rješavanje sporova ugovorena nadležnost Arbitražnog suda za sport u kontekstu Konvencije o priznanju i izvršenju stranih arbitražnih odluka. ${ }^{4}$

U prikazu problematike, analizirani su formalni uvjeti valjanosti arbitražnih ugovora, istaknute su vrste pravnih akata sportskih organizacija i organizacija koje nadziru postupanje po općim načelima sporta u kojima se referentne arbitražne klauzule mogu pronaći, izloženi su određeni aspekti nenadležnosti CAS-a i razlozi za poništaj arbitražnih klauzula, te referentna, javno dostupna praksa CAS-a u pogledu svake od navedenih cjelina.

\section{POVIJESNI KONTEKST RAZVOJA CAS-A}

Pitanje pristanka na rješavanje sporova arbitražom jedno je od najznačajnijih pitanja kojem se u sportskoj arbitraži pristupa drugačije nego u ostalim vrstama arbitraže i koje, da bi se razumjelo, mora biti stavljeno u ispravan kontekst. U početku, sportski savezi imali su ustanovljena sudbena tijela za provođenje svojih propisa i odlučivanje o žalbama protiv disciplinskih odluka koje bi ta tijela donijela. Iako su sportski sporovi često uključivali sportske institucije, sportaši i klubovi nisu preferirali pokretati sporove pred tim institucijama, jer su imali stav da nacionalni sudovi nevoljko preispituju odluke ovih institucija. Protekom vremena, a ponajviše zbog povećanja ekonomskih interesa, klubovi i sportaši su u većoj mjeri počeli pokretati postupke pred sportskim tijelima, a i nacionalni sudovi su promijenili stav o intervenciji u sportske sporove. Međutim, sport po svojoj prirodi treba imati osigurane jednake uvjete za sve sportaše, što je nemoguće postići u uvjetima podijeljene pravde raznih nacionalnih institucija.

Kako sportska zajednica (kao opći pojam koji obuhvaća uglavnom ljude koji upravljaju pojedinim sportskim federacijama) nije mogla prihvatiti različite ishode u sporovima koji se bave istom pravnom problematikom, a sport ujedno sadrži i mnoge posebnosti koje mogu bolje razumjeti specijalizirani tribunali nego redovni suci, postignut je opći konsenzus među nositeljima udjela u sportu da je arbitraža

\footnotetext{
${ }^{4}$ Njujorška konvencija iz 1958.
} 
u odnosu na redovni parnični postupak pred državnim sudovima bolja opcija. Posljedično, kako bi se harmoniziralo sportsko pravo i ponudio jedinstveni postupak u svrhu povećanja jednakosti i pravne sigurnosti, 1984. godine osnovan je CAS.

CAS je danas u svijetu prihvaćen od, manje-više, svih sportskih federacija, kao vrhovna instanca sportske arbitraže, te je prema navodu Švicarskog federalnog suda postao „Vrhovni sud svjetskog sporta“ i „,nezaobilazna institucija u svijetu sporta“. Svaka sportska udruga ima svoje interne sudbene instance, čije odluke su podložne preispitivanju pred CAS-om. Stoga su u većini vremena sportaši podložni standardnim arbitražnim ugovorima sadržanima u statutima, pravilnicima i izjavama sportaša, tj. u referenci, a ne $u$ arbitražnim ugovorima koji bi bili rezultat pregovora. Ovaj neizravan i iznuđen pristanak, koji sportaši u biti ne mogu izbjeći, otvorio je vrata raznim etičkim raspravama. No, neovisno o tome, referentne arbitražne klauzule u statutima ili izjavama sportaša obično budu prihvaćene od nacionalnih sudova i posebice Švicarskog federalnog suda (što je posebno bitno jer je sjedište arbitraže u Švicarskoj), koji je priznao prisilni karakter sportske arbitraže, ali je ujedno potvrdio njezinu zakonitost, i to zbog činjenice što predstavlja jedinstveni supstitut državnim sudovima iz više razloga. Prije svega, s obzirom na to da je specijalizirana institucija, CAS je najprikladniji forum za donošenje odluka u polju sporta. Potom, CAS pruža dostatna jamstva nezavisnosti i nepristranosti. I konačno, postoji mogućnost osporavanja pravorijeka CAS-a pred nacionalnim sudom, u ovom slučaju Švicarskim federalnim sudom, ako arbitraža pođe po zlu. Tako je i Europski sud za ljudska prava u predmetima Mutu i Pechstein ${ }^{5}$ istaknuo da u slučaju prisilne arbitraže, ako je kao takva propisana zakonom, jamstva navedena u članku 6.1. Europske konvencije moraju biti zajamčena. Ovo pojašnjenje Suda pokazuje da je valjanost klauzule o prisilnoj arbitraži uvjetovana poštovanjem procesnih prava zajamčenih Europskom konvencijom. Činjenica da pristanak na nadležnost CAS-a u mnogim slučajevima nije dobrovoljan, dovela je do toga da je CAS usvojio procesna pravila visoke kvalitete i da pomno nadzire poštovanje procesnih prava stranaka. ${ }^{6}$

\section{UGOVOR O NADLEŽNOSTI ARBITRAŽNOG SUDA ZA SPORT}

Spor se može pokrenuti pred Arbitražnim sudom za sport (CAS) samo ako stranke sporazumno ugovore nadležnost CAS-a da odlučuje u konkretnoj pravnoj stvari. Članak R27 Zakonika o sportskoj arbitraži (dalje: Zakonik) navodi da će CAS biti nadležan odlučivati samo o sporovima u vezi sa sportom, slijedom čega bi sve druge vrste sporova morao odbiti, čak i u slučaju da stranke sporazumno odluče

5 Odluka Europskog suda za ljudska prava, Mutu i Pechstein v. Švicarska od 2. X. 2018. (zahtjevi br. 40575/10 i 67474/10).

6 Laurence Boisson de Chazournes \& Ségolène Couturier, CAS procedures and their efficiency (CAS Bulletin, Lausanne 2019/2), str. 9-12. 
ugovoriti nadležnost CAS-a. Napomene radi, CAS se do sada još uvijek nije niti u jednom predmetu oglasio nenadležnim uz obrazloženje da spor nije vezan za sport. ${ }^{7}$

Švicarsko pravo općenito ne sadrži definiciju pojma arbitražnog ugovora. Bilo kakav sporazum stranaka da jedan ili više sadašnjih ili budućih sporova budu riješeni na obvezujući način, pravorijekom jednog ili više arbitara, uz isključenje nadležnosti redovnih sudova, jest prihvatljiv. Uz navedeno, nije potreban pretjerani formalizam, izuzev da arbitražni ugovor bude u pisanom obliku, što znači da može biti sklopljen telegramom, faksom, e-mailom ili bilo kojim trećim oblikom komunikacije koja ostavlja (vjerodostojan) pisani trag. ${ }^{8}$

Nadležnost CAS-a u velikoj većini slučajeva ustanovljena je arbitražnim klauzulama sadržanima u statutima ili pravilnicima sportskih organizacija, odnosno izjavama koje sportaši potpišu kao preduvjet za pristupanje reprezentaciji ili nastupanje na međunarodnim natjecanjima, no već smo uvodno napomenuli da je pitanje u kojoj mjeri takve klauzule predstavljaju valjani i obvezujući arbitražni ugovor kojim je ugovorena nadležnost CAS-a.

Dakle, arbitražna klauzula u propisima federacija mogla bi se interpretirati kao (jednostrana) ponuda sportske organizacije da se određene kategorije sporova rješava arbitražom, a ta ponuda može biti prihvaćena članstvom osobe u takvoj organizaciji ili izričitom izjavom. U nedostatku arbitražne klauzule, članstvo osobe u sportskoj organizaciji ne može biti smatrano dvostranim ugovorom koji ispunjava pretpostavke članka R47 CAS Zakonika (odredbe o žalbenom arbitražnom postupku). Također, isticanjem prigovora nedostatka nadležnosti, smatra se da je tuženik izričito odbio ponudu za rješenje spora arbitražom, dok s druge strane, ukoliko ne bude istaknut prigovor na ponudu za rješavanje spora arbitražom, utoliko bi prešutno bio sklopljen arbitražni ugovor. Isto tako, ako tuženik ne prigovori nadležnosti CAS-a, smatrat će se da je suglasan da spor bude riješen pred navedenim arbitražnim sudom, što je uostalom i opće načelo svih arbitražnih postupaka na koje je primjenjiv švicarski zakon o međunarodnom privatnom pravu, ${ }^{9}$ sukladno kojem prigovori nenadležnosti moraju biti istaknuti prije bilo kakvog raspravljanja o činjenicama. ${ }^{10}$

Pitanje ovršnosti arbitražnih ugovora koji su sadržani u propisima sportskih organizacija razmatralo je u okviru pravne teorije više autora, koji su mahom iznosili stavove da takvo referiranje ne predstavlja valjani arbitražni ugovor, i to iz razloga što sportaš nema stvarnu mogućnost izbora, tj. ako bi sportaš odbio potpisati ugovor, ne bi se mogao natjecati. Unatoč tome, Švicarski federalni sud zauzeo je stav da sustav brzog i uniformnog rješavanja sporova u međunarodnom sportu mora imati prednost pred pravom sportaša da u njezinu ili njegovu predmetu sude redovni sudovi, pod uvjetom da sustav rješavanja sporova strogo poštuje načelo pravičnosti. 1048.

Lewis and Taylor, Sport: Law and Practice, trece izdanje (Bloomsbury Professional, 2014.), str.

Ibid.

9 Eng. Private international law act (PILA)

10 Mavromati \& Reeb, The Code of the Court of Arbitration for Sport, Commentary, Cases and Materials, (Wolters Kluwer, 2015), str.34. 
Opseg obveze stranaka da sporove rješavaju arbitražom pred CAS-om, ovisit će o tekstu arbitražnog ugovora. Prema švicarskom pravu, kao primjenjivom lex arbitri, ugovori se interpretiraju u svjetlu načina kako su pisani i okolnostima pod kojima su stranke pristupile ugovoru, no bitno je istaknuti kako nema uniformnosti arbitražnih klauzula sadržanih u propisima sportskih organizacija, pa je iste nužno pažljivo pročitati kako bi se utvrdilo je li CAS nadležan odlučivati u određenom sporu. ${ }^{11}$

\subsection{Predmet Korda}

U praksi se pojavio i jedan zanimljiv slučaj, gdje je suština spora bila interpretacija arbitražnog ugovora u kontekstu aktivne legitimacije samo jedne od stranaka arbitražnog ugovora da pokrene postupak pred CAS-om. Činjenična podloga bila je ta da je tenisač Petr Korda potpisao prijavnicu za natjecanje na Wimbledonu 1998., koja prijavnica je sadržavala odredbu o vezanosti igrača antidopinškim programom Međunarodne teniske federacije (dalje: Program ITF-a). Navedenim Programom ITF-a osnovano je antidopinško žalbeno vijeće sa zadatkom utvrđivanja je li postojala povreda antidopinških pravila iz Programa ITF-a. Također je određeno da odluka Vijeća ima biti konačna i obvezujuća za sve stranke, te da će: „za rješavanje svih sporova koji proizađu iz odluka antidopinškog žalbenog vijeća nadležan biti žalbeni odjel Arbitražnog suda za sport (CAS), koji će odlučivati prema odredbama Zakonika sportske arbitraže.“

Igraču Kordi je analizom uzoraka u akreditiranom laboratoriju u Lausanni utvrđeno postojanje zabranjene supstance u organizmu, čime je utvrđen prekršaj antidopinških pravila iz Programa ITF-a. Korda je podnio žalbu žalbenom vijeću ITF-a, koje je prihvatilo Kordin navod da posebne okolnosti (iz Pravilnika ITF-a) opravdavaju smanjenje sankcije koja mu je izrečena.

ITF je potom uložio CAS-u žalbu na odluku žalbenog vijeća ITF-a, dok je Korda pred engleskim sudovima zatražio donošenje privremene mjere zabrane podnošenja navedenog pravnog lijeka, zbog stava da odredbe Programa ITF-a to dopuštaju samo sportašu (ne i ITF-u). Engleski je žalbeni sud odredbe rastumačio „,u kontekstu cjelokupnog ugovora, ... u odnosu na činjeničnu osnovu i okolnosti slučaja“, te zaključio da Program ITF-a predstavlja izvršan sporazum kojim je ugovorena nadležnost CAS-a za odlučivanje o navodima obje strane u pogledu ispravnosti odluke Žalbenog vijeća. ${ }^{12}$ U konačnici, postupak je održan pred žalbenim vijećem CAS-a, koje je pravorijekom usvojilo žalbu ITF-a i preinačilo odluku žalbenog vijeća ITF-a na način da je igraču Petru Kordi izrečena suspenzija u periodu od 12 mjeseci. ${ }^{13}$

11 Ibid., str. 1049

12 Korda v. ITF Ltd (1999.) Independent, Odluka AII ER (D) 337 (CA) od 21. IV. 1999.

13 CAS 99/A/223 International Tennis Federation (ITF). Petr Korda, pravorijek od 31. VIII. 1999., dostupno na https://arbitrationlaw.com/sites/default/files/free_pdfs/CAS\%2099-A-223\%20ITF\%20v\%20 K\%20Award.pdf. 


\subsection{Predmeti IAAF-a-Olimpijske igre u Sydneyu}

Ad hoc arbitražna vijeća na Olimpijskim igrama u Sydneyu također su prihvaćala nadležnost u predmetima koji su im podneseni na rješavanje. Tri predmeta uključivala su Međunarodnu atletsku federaciju (IAAF) koja u to vrijeme još uvijek nije prihvatila nadležnost CAS-a, slijedom čega je prigovorila rješenju kojim je imenovana strankom u navedenim arbitražnim postupcima. Međutim, Arbitražno je vijeće odbilo prethodno istaknuti prigovor uz obrazloženje da su ,pristupanjem olimpijskom pokretu i sudjelovanjem na Olimpijskim igrama, međunarodne federacije [uključujući IAAF] akcesorno prihvatile arbitražnu klauzulu iz Olimpijske povelje“14, a arbitražna klauzula propisana je člankom 61. i glasi: „1. Odluke Međunarodnog olimpijskog odbora [dalje: MOO] su konačne. Svaki spor koji se odnosi na primjenu ili tumačenje može riješiti isključivo Izvršni odbor MOO-a i, u određenim slučajevima, arbitraža pred Arbitražnim sudom za sport [CAS]; 2. Svaki spor nastao prigodom ili u vezi olimpijskih igara podnosi se isključivo Arbitražnom sudu za sport [CAS], sukladno Zakoniku sportske arbitraže.“"15

\section{VALJANOST REFERENTNIH ARBITRAŽNIH KLAUZULA: PITANJE PRISTANKA ILI FORME?}

Često se arbitražni ugovor ne može pronaći izravno u izjavama stranaka, već u nekom drugom izvoru, na koji se ugovorne strane pozivaju pri sklapanju pravnog posla (kao što su Opći uvjeti npr.).

Prema UNCITRAL-ovom Model-zakonu, arbitražne klauzule u referenci su valjane (bez obzira na formalne pretpostavke) ako čine sastavni dio ugovora. Članak 7 UNCITRAL-ovog Model-zakona, međutim, ostavlja pitanje pristanka neodgovorenim. Jedan prijedlog rješenja bio bi tumačiti takva pitanja prema ,načelu povjerenja“" koje sadrži članak 1. švicarskog Zakona o obveznim odnosima i prema kojem referenca treba biti konkretna i precizna, a dokument koji sadrži arbitražnu klauzulu mora biti jasno sastavljen i poznat ugovornim stranama. Opseg u kojem je opća referenca dostatna također treba biti utvrđen prema načelu povjerenja. Smatra se da je stranka pristala na opću referencu ako nije zahtijevala bilo kakvu rezervaciju, te je bila svjesna postojanja arbitražne klauzule. ${ }^{16}$

Sukladno članku R27 Zakonika sportske arbitraže, arbitražni ugovor u pogledu žalbenih postupaka možemo pronaći u sadržaju statuta/pravilnika federacija ili sportskih tijela koja su donijela odluke protiv kojih se žalba može izjaviti. U rijetkim se slučajevima dogodi da stranke sklope poseban sporazum, kako bi se mogle žaliti CAS-u na odluku federacije ili drugog sportskog tijela. U praksi, međutim, sportaši službeno ne postupaju prema odredbama statuta međunarodnih federacija,

\footnotetext{
14 Baumann v IOC, NOC Njemačka i IAAF, CAS OG 2000/006, CAS Digest II, str. 633-644.

15 Olimpijska povelja, verzija od 26. VI. 2019., dostupna na https://stillmed.olympic.org.

16 Mavromati \& Reeb, op. cit. u bilj. 6., str. 35.
} 
koji sadrže arbitražne klauzule, jer statuti klubova ili nacionalnih federacija sadrže samo referencu na obveze uključene u statute međunarodnih federacija. Arbitražna klauzula u referenci može biti specijalna ili opća, pri čemu je specijalna sadržana u već postojećem (točno određenom) dokumentu, na koji se stranke arbitražnoga ugovora pozivaju, uz uvjete propisane čl. 178. st. 1. PILA, dok se opća samo poziva na izvor/dokument, ali ne i na arbitražnu klauzulu koja je sadržana u tom dokumentu. ${ }^{17}$

Prema članku 12. švicarske PILA-e, opća referenca u načelu je prihvaćena, međutim postoje doktrinarno različiti stavovi. Tako je u predmetu Mariupol Basketball Club v. L. B. ${ }^{18}$ arbitražno vijeće zauzelo stav da izolirana referenca „,i CAS“ („Arbitar i CAS će donijeti odluku u sporu ex aequo et bono“) nije dostatna da bi se utvrdila nadležnost CAS-a bez postojanja posebnog sporazuma stranaka. Arbitražno vijeće je ovaj zaključak donijelo također imajući u vidu da standardni postupak pred FIBA-om izričito isključuje nadležnost CAS-a, još od formiranja BAT-a, slijedom čega je dodatak , i CAS“ očito omaška u pisanju. ${ }^{19}$

Švicarski federalni sud je stava da je kod arbitražnih klauzula u referenci problem u pristanku, a ne u formi arbitražnih ugovora. Prema okolnostima slučaja, ponašanje stranaka može se tumačiti kao njihov pristanak na opću referencu u dokumentu koji sadrži arbitražnu klauzulu, slijedom čega problem prelazi s forme u kojoj su stranke ugovorile arbitražno rješavanje sporova na pitanje pristanka na arbitražu, te bi sportaš trebao biti svjestan odredbi pravilnika federacije kad god bude zahtijevao (od iste) odobrenje za sudjelovanje na natjecanju. ${ }^{20}$

Tako je u predmetu S. v. P. FC ${ }^{21}$ utvrđeno da je plaćanje spornog iznosa regulirano Sporazumom o raskidu ugovora koji nije sadržavao arbitražnu klauzulu, već samo referirao na arbitražnu klauzulu sadržanu u drugom ugovoru, tj. glavnom ugovoru. Navedenom arbitražnom klauzulom stranke su se sporazumjele sve sporove podvrgnuti arbitraži pred Arbitražnim sudom za sport. Arbitražno je vijeće smatralo takvu arbitražnu klauzulu valjanom jer su Sporazumni raskid ugovora potpisale obje ugovorne strane, a arbitražna klauzula iz osnovnog ugovora bila je u pisanom obliku. No ono što komplicira situaciju jest načelo dobre vjere koje se razvija u sudskoj praksi i prema kojem, bez obzira na ispunjenje forme, ipak nije valjan arbitražni ugovor ako je stranka koja je uvrstila referencu znala ili trebala znati da druga strana ne bi pristala sklopiti ugovor pod navedenim okolnostima.

17 Ibid., str. 36.

8 CAS 2013/A/3263, pravorijek od 14. III. 2014.

9 Mavromati \& Reeb, op. cit. u bilj. 6, str. 36.

20 Mavromati \& Reeb, op . cit. u bilj. 6., str. 37; Odluka švicarskog federalnog suda 4P_230/2000 od 7. II. 2001., u predmetu S. Roberts v. FIBA (Bull. ASA 2001, str. 523).

21 Pravorijek CAS 2007/O/1229 od 18. XII. 2007., toč. 46. 


\subsection{Predmeti Dodô i Busch}

Da bi Arbitražni sud za sport sa sjedištem u Švicarskoj bio nadležan, člankom 178.1 švicarskog Zakona o međunarodnom privatnom pravu (dalje: PILA) propisano je obvezno postojanje arbitražnog sporazuma, i to u pisanom obliku: ,Sto se tiče oblika, arbitražni sporazum valjan je ako je sastavljen u pisanom obliku, putem telegrama, teleksa, telekopira ili bilo kojeg drugog sredstva komunikacije koje ostavlja pisani trag". S tim u vezi treba napomenuti da je Federalni sud usvojio vrlo liberalan pristup prema arbitraži CAS-a na način da je presudom, 4A_428/2011 od 13. veljače 2012., u predmetu Wickmayer/Malisse ocijenio „,dobronamjernom konsenzualnu prirodu sportske arbitraže s ciljem poboljšanja brzog rješenja sporova od strane specijaliziranih arbitražnih sudova, popust CAS-a, koji pružaju dostatna jamstva neovisnosti i nepristranosti“. Zbog dobronamjernog pristupa, Federalni sud je kod procjene jesu li Zahtjevi iz članka 178.1 PILA-e zadovoljeni, smatrao prikladnijim dati značajniju težinu ponašanju stranaka nego se ograničiti samo na preispitivanje jesu li stranke ispunile njegove formalne uvjete. Tako je Federalni sud već citiranom presudom 4A_428 / 2011 od 13. veljače 2012., u predmetu Wickmayer/Malisse, utvrdio da „ovisno o okolnostima, postupanje u dobroj vjeri može biti valjani supstitut poštovanju formalnih pretpostavki““. ${ }^{22}$

Savezni sud očitovao je ovaj ,pro-sportsko-arbitražni“ pristup u slučajevima kada je morao utvrditi je li zakonita odluka arbitražnog vijeća CAS-a kojom se isto oglasilo nadležnim odlučivati u sporu na temelju referentne arbitražne klauzule.

Načelno, prema sudskoj praksi Švicarskog federalnog suda, CAS se može oglasiti nadležnim na temelju pristanka nekog sportaša ili kluba na sportska pravila koja uključuju opću referencu na statute i pravilnike saveza koji sadrže arbitražnu klauzulu CAS-a. Švicarski federalni sud je tako presudom 4A_460/2008 od 9. siječnja 2009., u predmetu FIFA \& WADA v. STJDF, CBF \& Ricardo Lucas Dodô (dalje u tekstu: Dodô), odbio žalbu i potvrdio pravorijek CAS-a 2007/A/1370-1376. U navedenom predmetu arbitražno vijeće CAS-a je utvrdilo da zbog činjenice što statut brazilske nogometne konfederacije, koje je igrač Dodô bio član, propisuje da svi sportaši moraju postupati prema pravilima FIFA-e, igrač je također bio vezan arbitražnom klauzulom u statutu FIFA-e, koja omogućuje FIFA-i i WADA-i pravo žalbe protiv odluka nacionalnih saveza u antidoping predmetima. Potvrdivši CASov pravorijek u predmetu Dodô, Švicarski federalni sud je naveo da je takva odluka u skladu sa ,sudskom praksom koja smatra valjanom opću referencu na arbitražnu klauzulu sadržanu u statutima udruga“. Ovaj stav također je u skladu i s prethodno odlučenim predmetom Roberts, ${ }^{23}$ gdje je zauzet stav da „referenca ne treba eksplicitno citirati arbitražnu klauzulu, već je dostatna opća uputa na dokument koji sadrži takvu klauzulu, te da se pretpostavlja da sportaš priznaje propise federacije

22 Coccia Massimo, The jurisprudence of the Swiss Federal Tribunal on challenges against CAS awards, CAS Bulletin, 2/2013, str. 8.

23 Presuda Švicarskog federalnog suda, broj 4P 230/2000 od 7. veljače 2001. 
s kojima je upoznat ako se već prijavio toj federaciji za natjecanje ili ishođenje igračke dozvole“". ${ }^{24}$

Međutim, Švicarski federalni sud ipak ne prihvaća svaku vrstu referentne arbitražne klauzule, za što je najbolji primjer presuda u predmetu A. protiv WADA$\mathrm{e},{ }^{25}$ gdje je meritum spora bila valjanost arbitražnih klauzula u pristupnicama pred natjecanje. U navedenom predmetu, činjenice su bile da je sportaš svake godine potpisivao registracijski obrazac kako bi mogao sudjelovati u hokejaškim natjecanjima organiziranima od Svjetske hokejaške federacije. Navedeni obrazac, među ostalim, sadržavao je sljedeći tekst. „Ja, niže potpisani, jamčim svojom čašću a) da sam podložan nacionalnoj federaciji koju predstavljam ... 1) obvezujem se poštivati i postupati po Statutu IIHF-a, te ostalim propisima (uključujući propise vezane za medicinsku doping kontrolu) i odlukama IIHF-a i upravnog tijela organizatora natjecanja u svim stvarima koje uključuju disciplinske mjere, ne uključivati bilo koju treću osobu izvan IIHF natjecanja i/ili Statuta, drugih propisa i odluka donesenih od IIHF-a, do trenutka kada budu iscrpljena sva pravna sredstva unutar IIHF-a, u kojem slučaju se obvezujem bilo koji takav spor pokrenuti pred Arbitražnim sudom za sport (CAS) u Lausanne, Švicarska, radi konačnog rješenja. "26

Činjenice su bile da je sportaš odbio dati uzorak urina kontroloru pri testiranju izvan natjecanja koje je inicirala nacionalna antidopinška agencija. Nakon kratkog perioda suspenzije, što ga je sportašu nametnulo nacionalno disciplinsko tijelo, WADA se žalila CAS-u na navedenu odluku, te je CAS utvrdio svoju nadležnost za rješavanje spora na osnovi registracijskog obrasca koji je sportaš potpisao kako bi mogao sudjelovati na Svjetskom prvenstvu u hokeju na ledu 2007., a koji obrazac je sadržavao poprilično široku stipulaciju nadležnosti. U konkretnom slučaju, Švicarski federalni sud je ipak zaključio da registracijski obrazac koji je sportaš potpisao za konkretno natjecanje ne sadrži valjanu arbitražnu klauzulu u korist CAS-a za sve vrste sporova i natjecanja. Registracijski obrazac koji potpiše sportaš u okviru različitih prvenstava, svaki put je vezan za konkretno određeno prvenstvo, te se ne odnosi na bilo kakve sporove koji općenito mogu nastati. Prema načelu dobre vjere, potpisom registracijskog obrasca prije konkretnog natjecanja, sportaš nije bio dužan pretpostaviti da ulazi u širi arbitražni ugovor izvan okvira samog natjecanja, odnosno opći pristanak nije bilo moguće izvesti iz sudjelovanja na konkretnom natjecanju. Stoga je Švicarski federalni sud ograničio arbitražne klauzule iz registracijskog obrasca na konkretno natjecanje, te zaključio da se arbitražna klauzula ne proteže na dopinšku kontrolu temeljem koje je nastala sporna odluka. ${ }^{27}$

No, bez obzira na to što na prvi pogled predmeti sadrže dijametralno suprotna obrazloženja odluka, oni su u biti usklađeni na načelnoj razini. Naime, u predmetu Dodô, igrač je nesporno bio registriran kao profesionalni nogometaš pri brazilskoj

24 Ibid.

25 Presuda Švicarskog federalnog suda, 4A_358/2009 od 6. studenoga 2009., predmet Busch, točka 3.2.3., kojom je poništen pravorijek CAS 2008/A/1564, WADA protiv F.B. i IIHF, od 23. lipnja 2009.

26 Coccia, op. cit. u bilj. 17.

27 Op. cit. u bilj. 19. 
nogometnoj konfederaciji, te je nesporno potpisao ugovor o igranju sa svojim klubom i izrijekom istaknuo da je upoznat s pravilima konfederacije (kojima je propisano da registrirani igrači moraju i obvezuju se postupati prema svim pravilima FIFA-e, koja izričito pak navode pravo WADA-e i FIFA-e na podnošenje žalbe CAS-u protiv odluka nacionalnih doping tijela). Stoga je vijeće takvu referentnu arbitražnu klauzulu utvrdilo valjanom, što je potvrdio i Śvicarski federalni sud. U predmetu Busch, osim činjenice da je vijeće CAS-a svoju odluku zasnovalo samo na igračevom potpisu registracijskog obrasca (koji nije bio dostatan zbog činjenice što se povreda pravila o dopingu nije dogodila na natjecanju u organizaciji IIHF-a), nikakav ugovor o igranju koji bi potpisao igrač ili pravilo igračeve nacionalne federacije (njemačke hokejaške federacije) nije navodilo da bi igrač bio dužan postupati prema pravilima IIHF-a. Uz to, IIHF se oglasio nenadležnim, dok pravila njemačke hokejaške federacije i IIHF-a ne sadrže odredbe koje bi dopuštale WADA-i ili IIHF-u pravo na podnošenje žalbe CAS-u na odluku u vezi s dopingom koju je donijela njemačka hokejaška federacija. Ove činjenične razlike navele su Švicarski federalni sud da odbije navode o postojanju referentne arbitražne klauzule. ${ }^{28}$

\section{IZRAVNE I NEIZRAVNE ARBITRAŽNE KLAUZULE U NOGOMETU}

Tip arbitražnih ugovora potreban da bi CAS bio nadležan često je bilo pitanje raznim arbitražnim vijećima u predmetima vezanima za nogomet. Od posebne je važnosti bilo tumačenje dvije odredbe iz Statuta FIFA-e vezane za CAS. Prije svega, propisano je da su „Odluke Komisije za žalbe [] neopozive i obvezujuće za sve odnosne strane. Ova odredba predmetom je žalbi koje se podnose Arbitražnom sudu za sport (CAS).“29 Nadalje, propisano je da „Žalbe na konačne odluke pravnih tijela FIFA-e i odluke konfederacija, saveza članova ili liga podnose se CAS-u u roku od 21 dan od dana primitka odnosne odluke. ${ }^{\text {"30 }}$ Iako Statut FIFA-e uključuje klauzulu koja priznaje nadležnost CAS-a općenito, ali i u žalbenim postupcima protiv odluka tijela organizacije, ovaj arbitražni ugovor ograničen je samo na odluke tijela FIFA-e, jer ,... CAS neće razmatrati žalbe koje proizlaze iz: ... c) odluka protiv kojih se može podnijeti žalba neovisnom i valjano konstituiranom arbitražnom sudu priznatom prema odredbama saveza ili konfederacije. ${ }^{\text {"31 }} \mathrm{U}$ konačnici, propisano je: „Konfederacije, savezi članovi i lige suglasni su priznati CAS kao neovisno pravno tijelo i obvezuju se da će njihovi članovi, pridruženi igrači i službene osobe poštivati odluke CAS-a. Ista obveza primjenjuje se na posrednike i licencirane posrednike za ugovaranje utakmica." ${ }^{32}$

\footnotetext{
28 Coccia, op. cit. u bilj. 11, str. 12.

Članak 55. st. 3. Statuta FIFA-e iz kolovoza 2018.

Članak 58. st. 1. Statuta FIFA-e iz kolovoza 2018.

Članak 58 st. 3. Statuta FIFA-e iz kolovoza 2018.

Članak 59. st. 1. Statuta FIFA-e iz kolovoza 2018.
} 
Dok u slučaju odluke koju donesu tijela FIFA-e ne postoji problem nadležnosti CAS-a zbog postojanja čl. 58. st. 1. Statuta FIFA-e iz kolovoza 2018., situacija je složenija u slučaju sporova u koje je uključen nacionalni savez (član FIFA-e) i sportaš. U ovom slučaju, ne možemo reći da je priznanje CAS-a u Statutu FIFA-e dostatno za žalbe protiv odluka koje donesu nacionalni savezi u sporovima s čisto domaćim obilježjem, pa se članak 58. st. 1. Statuta FIFA-e ne bi mogao smatrati općim, tj. sveobuhvatnim, arbitražnim ugovorom koji favorizira CAS u svim sporovima s nogometnim obilježjem, pri čemu se referiranje članka 57. st. 1. Statuta FIFA-e ${ }^{33}$ za rješavanje sporova između FIFA-e, saveza članova, konfederacija, liga, klubova, igrača, službenih osoba, posrednika i licenciranih posrednika za ugovaranje utakmica na CAS ne bi moglo smatrati dostatnim za utvrđivanje nadležnosti Arbitražnog suda za sport. ${ }^{34}$

Potreba za izravnom referencom na CAS ponovljena je u brojnim pravorijecima Arbitražnog suda za sport. ${ }^{35}$ Jedina iznimka propisana je člankom 58. stavkom 5 i 6 Statuta FIFA-e koji ovlašćuje FIFA-u i WADA-u da podnesu žalbe CAS-u protiv odluka u vezi s dopingom što su ih donijele nacionalne federacije. Pravila FIFA-e i ,priznanje“ CAS-a iz članka 57. st. 1. Statuta FIFA-e samo po sebi ne predstavlja osnovu za arbitražu, već preporuku za uvođenje pravila koje omogućuje arbitražu pred CAS-om. Nadalje, CAS je potvrdio da Statut FIFA-e ne sadrži kogentne odredbe koje bi obvezivale tuženika (nacionalni nogometni savez) da dozvoli mogućnost podnošenja žalbe na odluke saveza. Činjenica da stranka ima pravo zahtijevati od vanjskog sudbenog tijela ocjenu odluke (tj. tijela neovisnog od nacionalnog nogometnog saveza) nije dostatna za važenje arbitražne klauzule u korist CAS-a. ${ }^{36}$

Stoga, pravila UEFA-e i FIFA-e, u najbolju ruku mogu tvoriti tipski i neizravan arbitražni ugovor, koji ne može imati prednost pred izravnom arbitražnom klauzulom uključenom u ugovor stranaka. Statut UEFA-e ne sadrži arbitražnu klauzulu koja može biti korištena na nacionalnoj razini, ali je dostatno da nacionalni savezi priznaju nadležnost CAS-a „kako je navedeno u važećem Statutu““ ${ }^{37}$ Statut FIFA-e ne sadrži arbitražnu klauzulu za rješavanje sporova u kojima FIFA nije uključena.

Arbitražna vijeća CAS-a također su naglašavala razliku između ,prihvaćanja“ ili „priznanja“ CAS-a i „odabira“ CAS-a kao foruma za rješavanje sporova koji mogu proizaći među strankama. ${ }^{38}$ Članak 59. Statuta FIFA-e ne sadrži arbitražnu

33 Koji glasi: „FIFA priznaje neovisni Arbitražni sud za sport (CAS) sa sjedištem u Lausanni (Švicarska)“.

34 CAS 2011/O/2588, Pravorijek od 27. II. 2012., u predmetu F. v. K., stavak 68 f.

35 CAS 2004/A/676, Ismailia SC v. CAF, Pravorijek od 15. XII. 2004.; CAS 2005/A/952, A. Cole v. FAPL, Pravorijek od 24. I. 2006.; CAS 2008/A/1656, PFC Botev 1912 - Plovdiv AD v. BFU \& Hristov, Privremena mjera od 18. XI. 2008.; CAS 2012/A/2688, P. Samarinda, D. Sidoardjo FC, Pelita Jaya FC, L. i E. v. PSSI, Pravorijek od 12. IV. 2012.; CAS 2013/A/3199, Rayo Vallecano de madrid SAD v. RFEF, Pravorijek od 22. X. 2013.

36 Taj stav obrazložen je u odluci CAS 2011/A/2472, Al-Wehda Club v. SAFF, Pravorijek od 12. VIII. 2011., paragraf 60; Mavromati \& Reeb, op. cit. u bilj. 6, str. 39-40.

37 CAS 2007/O/1440, P. v. C., Pravorijek o nadležnosti od 21. X. 2008., para. 6.20.

38 CAS 2009/A/1910, Telecom Egypt Club v. EFA, Pravorijek o nadležnosti od 9. IX. 2010. 
klauzulu, već samo predlaže nacionalnim savezima da priznaju CAS i inkorporiraju pravila u svoje statute ili pravilnike, koja zabranjuju obraćanje redovnim sudovima u korist arbitraže pred CAS-om ili drugim „,nezavisnim i propisno sastavljenim arbitražnim tribunalom priznatim prema pravilima saveza. ${ }^{\text {“39 }}$ Stoga je preporučljivo da nacionalni savezi izrade precizna pravila i inkorporiraju izričitu arbitražnu klauzulu u korist CAS-a ili nacionalnih arbitražnih institucija. ${ }^{40}$

$\mathrm{Na}$ tragu prethodno navedenoga jest i obrazloženje Pravorijeka CAS-a 2008/O/1694 od 5. lipnja 2009., u predmetu P. v. B., gdje je istaknuto da se Statuti nacionalnih nogometnih saveza moraju tumačiti na način koji promovira načelo pravne sigurnosti za svoje članove.

Bilo je slučajeva gdje su stranke navodile da je CAS nadležan odlučivati u predmetu zbog toga jer sudbena vlast na nacionalnoj razini nije „nezavisna“ ili „,propisno sastavljena“, sukladno članku 58. st. 3. Statuta FIFA-e. ${ }^{41}$ U ovim slučajevima nije na CAS-u da prihvati nadležnost, odnosno činjenica da nacionalni tribunali ne ispunjavaju uvjet nezavisnosti ne može voditi akcesorno do utvrđivanja nadležnosti CAS-a. Samim time, ako Statut nacionalnog saveza nije u skladu sa Statutom FIFA-e/UEFA-e, na tim je organizacijama da nametnu nacionalnom savezu nužne sankcije radi usklađenja odredbi. ${ }^{42}$

\section{SPOROVI VEZANI ZA POVREDU PRAVILA O ANTIDOPINGU I VALJANOSTI ARBITRAŽNE KLAUZULE}

Prema članku 13.2 Pravilnika Svjetske antidopinške agencije (WADA) iz 2015. (stavak 13.2.1. „Žalbe koje se odnose na sportaše međunarodne razine ili na međunarodne sportske događaje“) ,[u] slučajevima nastalima na međunarodnim sportskim događajima ili u slučajevima koji se odnose na sportaše međunarodne razine na odluku se može žaliti isključivo CAS-u.“ Za žalbe koje uključuju „druge sportaše ili druge osobe“, člankom 13.2.2 propisano je da se „žalba protiv odluke može podnijeti nezavisnom i nepristranom tijelu sukladno pravilima utvrđenim od nacionalne antidopinške organizacije“, pod posebnim uvjetima i prema načelima propisanima u članku 13.2.2 (pravovremeno održavanje ročišta; pošteno i nepristrano vijeće; pravo na zastupanje i slobodan izbor pravnog zastupnika o vlastitom trošku; te pravovremena, pisana i obrazložena odluka). U komentaru članka 13.2.2 navedeno je da ,antidopinška organizacija može izabrati postupanje

39 CAS 2013/A/3058, FC Rad v. Nebojša Vignjević, Pravorijek o nadležnosti od 14. VI. 2013., para 1.17; CAS 2011/A/2483, Iraklis Thessaloniki FC v. HFF \& GSL, Pravorijek od 21. XII. 2011., para. $74 \mathrm{f}$.

40 Mavromati \& Reeb, op. cit. u bilj. 6, str. 40.

41 Kojim je propisano da „,... CAS neće razmatrati žalbe koje proizlaze iz: ... c) odluka protiv kojih se može podnijeti žalba neovisnom i valjano konstituiranom arbitražnom sudu priznatom prema odredbama saveza ili konfederacije."

42 CAS 2011/A/2483, Iraklis Thessaloniki FC v. HFF \& GSL, Pravorijek od 21. XII. 2011., para. 55. 
po ovom članku na način da svojim sportašima nacionalne razine pruži mogućnost žalbe izravno CAS-u. ${ }^{43}$

Odredbe članka 13. WADA-inog Pravilnika nisu dostatne same po sebi za utvrđivanje opće i valjane arbitražne klauzule u korist CAS-a. Međunarodne su federacije pozvane uvrstiti odredbe Pravilnika WADA-e u svoje Statute/ Pravilnike, bez čega CAS nema ovlast odlučivati u žalbenom postupku. Navedeno je bilo predmetom odluke u predmetu gdje arbitražno vijeće nije pronašlo nikakvu referencu u Pravilniku međunarodne federacije koja bi sadržavala kogentnu odredbu koja bi obvezivala nacionalne saveze da dozvole mogućnost podnošenja žalbe protiv njihovih odluka u svakom slučaju. ${ }^{44}$ Umjesto toga, vijeće je utvrdilo da je jedina obveza njegovih nacionalnih saveza i igrača u skladu s člankom 16. Pravila međunarodne federacije ograničena na vrijeme sudjelovanja u događajima koje je međunarodna federacija organizirala: budući da se doping testiranja nisu odvijala tijekom međunarodnog događaja, već tijekom nacionalnog događaja koji je organizirao nacionalni savez, Vijeće je zaključilo da to nije obuhvaćeno člankom 16. Pravila međunarodne federacije i da se članak 16. ne može tumačiti kao stvaranje obveze ili sporazuma koji će omogućiti podnošenje žalbe CAS-u prema okolnostima tog slučaja. Također, pravorijekom (o nadležnosti) ${ }^{45}$ Vijeće je ocijenilo da nije nadležno zbog činjenice da nije bilo međunarodnog događaja i da sportaš nije na međunarodnoj razini. U tom pogledu, svaka međunarodna federacija dužna je osigurati da njezini članovi usvoje antidoping pravila u skladu s Pravilnikom WADA-e, koja pravila međunarodnoj federaciji, njezinoj članici ili WADA-i omogućuju da ulože žalbu na sve odluke prema svojem izboru. Međutim, sportaši ne trebaju osobno potpisati prijavnice prije natjecanja, već je dovoljno da ih pravilno potpiše nacionalni olimpijski odbor sportaša, ${ }^{46}$ a taj je stav u konačnici i potvrđen pravorijekom CAS-a ${ }^{47} \mathrm{U}$ konkretnom slučaju, prijavni obrazac uredno je potpisao nacionalni savez i potpis nacionalnog olimpijskog odbora bio je u ime svih sportaša, uključujući i žalitelja. Vijeće je zaključilo da su po osnovi Pravila 9. Uvjeta za pristupanje, antidoping propisi Međunarodnog olimpijskog odbora i Olimpijska povelja primjenjivi na sportaša u ime kojeg je potpisan prijavni obrazac (članak 2. prijavnog obrasca), čak ako ga sportaš nije osobno potpisao. ${ }^{48}$

Vijeća CAS-a u više su navrata navodila (što je Švicarski federalni sud također potvrdio) da su, pod određenim okolnostima, opće reference na pravila FIFA-e dovoljne da opravdaju njihovu primjenu, a samim tim i da utvrde nadležnost CAS-a, kao u antidopinškim predmetima, gdje jasne odredbe stavaka 5. i 6. članka 58.

43 Mavromati \& Reeb, op. cit. u bilj. 6, str. 42.

44 CAS 2006/A/1190 od 28. VI. 2006., WADA v. Pakistan Cricket Board \& Akhtar \& Asif.

45 CAS 2013/A/3236, Pravorijek od 20. veljače 2014., par. 49f.

46 Npr. prije Olimpijskih igara.

47 CAS 2007/A/1290 od 4. I. 2008., R. v. IOC. U navedenom slučaju, Pravilom 9 Uvjeta za pristupanje propisano je: „nacionalni olimpijski odbor ovime potvrđuje i jamči da su sva relevantna pravila, uključujući sva prethodno navedena, stavljena na znanje natjecatelju i da je nacionalni olimpijski odbor ovlašten od (i u ime) referentne nacionalne sportske federacije potpisati ovaj obrazac prijave, uz odobrenje odgovarajuće međunarodne federacije“.

48 Mavromati \& Reeb, op. cit. u bilj. 6., str. 42. 
FIFA-inog statuta omogućuju vijeću CAS-a da zadrži nadležnost nad odlukom nacionalne federacije o doping materiji izričitim pozivanjem statuta nacionalne federacije na statute FIFA-e. ${ }^{49}$

Švicarski federalni sud se također bavio pitanjem valjanosti arbitražnog sporazuma, posebno ponudom za zaključivanje sporazuma u slučajevima vezanima za doping. Uvjeti iz članka 178. PILA-e moraju biti ispunjeni i arbitražni sporazum mora se tumačiti u skladu s općim načelima zakona, a posebno načelom dobre vjere. U slučajevima koji uključuju sportaše na nacionalnoj razini, trebalo bi utvrditi stvarni pristanak stranaka, a ovo načelo pretpostavlja izričitu izjavu namjere. S tim u vezi, pismo - u kojem se navodi: „Podsjetio bih vas da će odluka koju će donijeti nadležno disciplinsko povjerenstvo [nacionalnog saveza] naknadno... u žalbenom postupku, biti ispitana pred CAS-om u Lausanni, i to na vašu inicijativu ako s odlukom ne budete suglasni, ili na inicijativu IAAF-a ako odluka ne bude u skladu s pravilima IAAF-a. To će neizbježno dovesti do skupog i dugotrajnog arbitražnog postupka sve dok CAS ne donese konačnu presudu“ - ne može pretpostaviti stvarni pristanak stranaka (ili ponudu u dobroj vjeri za zaključivanje obvezujućeg arbitražnog sporazuma), već isključivo predstavlja percepciju IAAF-a o žalbenom postupku. ${ }^{50}$

U posljednjim godinama, nakon poznatog slučaja Pechstein, pitanje ima li sportaš pravo na pokretanje spora pred državnim sudovima unatoč valjanom arbitražnom sporazumu pokrenulo je brojne rasprave. Ukratko, sportašica je svojevoljno, ali bezuspješno, pred CAS-om pobijala sankciju koju joj je izrekla Međunarodna klizačka federacija. Njene žalbe pred CAS-om i Švicarskim federalnim sudom bile su odbijene, pa se sportašica na obje odluke žalila pred njemačkim državnim sudovima kako bi osporila nadležnost CAS-a, te pred Europskim sudom za ljudska prava (ECHR) kako bi se utvrdilo kršenje Europske konvencije o ljudskim pravima. Bez obzira na sve pokušaje, Sud u Strasbourgu odbio je navode Claudije Pechstein da CAS nije nezavisan i nepristran tribunal. Zaliteljica je svoje argumente bazirala uglavnom na načinu kako se arbitri selektiraju, odnosno, tvrdila je da se sportske federacije po tom pitanju ,previše pita“, a sportaše premalo, no njezine navode Europski sud za ljudska prava odbio je kao neosnovane. Također, njemačka se sportašica žalila i na činjenicu što joj nije usvojen zahtjev (iz 2009.) za javnim suđenjem, koju tvrdnju je Europski sud ipak smatrao osnovanom, čime je žaliteljici utvrđena povreda prava na pošteno suđenje iz čl. 6 . Europske konvencije i dosuđena kompenzacija od 8000 eura, ${ }^{51}$ no bez učinka na valjanost prethodno pobijane odluke CAS-a.

49 Tako je navedeno u predmetu CAS 2007/A/1370 \& 1376, FIFA v. STJD \& CBF\& R. Dodo \& WADA v. STJD \& CBF \& R. Dodo, pravorijek od 11. rujna 2008., para. $106 \mathrm{f}$.

50 Mavromati \& Reeb, op. cit. u bilj. 6, str. 43-44.

51 Presuda Europskog suda za ljudska prava u predmetu Mutu i Pechstein v. Švicarska, br. 40575/10 i 67474/10, od 2. X. 2018. 


\section{ARBITRAŽNI UGOVORI U SPOROVIMA BEZ MEĐUNARODNOG ELEMENTA PRED CAS-OM}

Trebali bismo razlikovati kriterij državljanstva spora pri određivanju primjenjivosti PILA-e prema švicarskom građanskom zakoniku i kriterija državljanstva jedne od stranaka prilikom definiranja koja se pravila trebaju primijeniti. Doista, u pravilima nekih međunarodnih federacija, npr. FIFA Pravila o statusu i transferima igrača ,čisto nacionalni“ slučajevi ili slučajevi koji se odnose na klubove koji pripadaju istom savezu trebali bi se rješavati na nacionalnoj razini. Razlika između nacionalne i međunarodne dimenzije predmeta može imati utjecaja i na nadležnost CAS-a, budući da se prema članku 24. FIFA Pravila o statusu i transferima igrača, samo protiv odluka koje je donio FIFA DRC može uložiti žalba pred CAS-om. Određena vijeća CAS-a raspravljala su o pitanju „međunarodnog karaktera“ spora i smatrala su da je dvojno državljanstvo igrača neprimjereno za opravdavanje spora s međunarodnim elementom u smislu Pravila o statusu i transferima igrača. Također je moguće da pravila nacionalne federacije predviđaju nadležnost CAS-a u slučajevima s međunarodnom dimenzijom ili u slučajevima sa „stranim elementom“. ${ }^{52}$

\section{PATOLOŠKE ARBITRAŽNE KLAUZULE}

Sudska praksa Švicarskog federalnog suda govori nam da, premda se postojanje arbitražne klauzule ne treba uzeti u obzir olako, kada je postojanje utvrđeno, opseg arbitražne klauzule može se interpretirati liberalno. ${ }^{53}$

Ovaj pristup usvojen je kada je Švicarski federalni sud potvrdio pravorijek CAS 2010/O/2129 od 17. ožujka 2011., između M i C, kojim je CAS utvrdio svoju nadležnost odlučivati u sporu gdje je njegova nadležnost bila ustanovljena tzv. patološkom arbitražnom klauzulom, i to uz obrazloženje da: „Nepotpune, nejasne ili kontradiktorne odredbe u arbitražnim klauzulama čine patološke klauzule. Dokle god se ne referiraju na obvezne sastojke arbitražnog ugovora, kao što je obveza pokretanja postupka pred arbitražnim tribunalom, takve klauzule nisu nužno nevaljane, već postoji mogućnost traženja rješenja tumačenjem odredbi, odnosno dopunom ugovora referiranjem na opće ugovorno pravo koje poštuje osnovnu namjeru stranaka da rješavanje spora podvrgnu arbitraži. ${ }^{\circ 54}$

U tom predmetu, stranke su se sporile oko interpretacije patološke (arbitražne) klauzule između igračeve agencije kao tužitelja i nogometnog kluba kao tuženika.

52 Primjer je predmet CAS 2010/A/2255, René Salomon Olembe Olembe v. Kayserispor Kulubu Dernegli, pravorijek od 16 rujna 2011., para. 49 ff. U navedenom predmetu, arbitražno je vijeće razmatralo odredbe arbitražnog tribunala turskog nogometnog saveza, sukladno članku 14. kojim je CAS određen kao nadležno tijelo u slučajevima sa „stranim elementom“ (ne nužno s međunarodnom dimenzijom), te slučajevima gdje bi se igrač mogao ,u nogometnom smislu“ smatrati strancem.

53 Švicarski federalni sud, Presuda 4A_103/2011 od 20. rujna 2011.

54 Švicarski federalni sud, Presuda 4A_246/2011 od 7. studenoga 2011., toč. 2.2.3. 
Prije priznanja CAS-a u Statutu FIFA-e, 2003. godine, stranke su sklopile ugovor o transferu kojim je ugovoreno da je ,u slučaju spora među strankama za odlučivanje o pravima i obvezama iz ovog ugovora nadležna Komisija FIFA-e ili UEFA-e“. Kada je spor nastao, tužitelj je podnio zahtjev za arbitražom pred FIFA-om, koja je utvrdila da nije u mogućnosti odlučivati u sporu, a sličan je bio i stav UEFA-e, pa je 2009. tužitelj zahtijevao od švicarskog državnog suda da imenuje arbitražni tribunal, što je sud odbio zbog nenadležnosti. Tužitelj je potom podnio zahtjev CAS-u. U pravorijeku (o prethodnom pitanju) donesenom 17. ožujka 2011., arbitražno je vijeće utvrdilo nadležnost CAS-a. U suštini, vijeće je smatralo: da su stranke imale zajedničku namjeru svoje sporove podvrgnuti arbitraži; da imenovanje institucije nije subjektivno bitno (ništa nije ukazivalo da strane ne bi izabrale arbitražu u slučaju da FIFA odbije rješavati spor), ali da su stranke željele instituciju specijaliziranu za sport sa sjedištem u Švicarskoj. Činilo se da je CAS najprikladniji forum, stoga je vijeće protumačilo klauzulu kao zamisao arbitraže na CAS-u. Treba napomenuti da je nogometni klub podnio žalbu švicarskom federalnom sudu protiv takvog pravorijeka tvrdeći da je vijeće CAS-a pogrešno utvrdilo svoju nadležnost. Švicarski federalni sud je, međutim, u odluci od 7. studenoga 2011. (4A_246/2011) potvrdio pravorijek i odbio žalbu. Kao rezultat, kada odlučuje o pitanjima o nadležnosti koja su rezultat patološke klauzule, vijeće CAS-a treba provjeriti (i) postoji li obostrani pristanak stranaka o točkama koje su objektivno ključne za zaključivanje arbitražnog sporazuma ( $\mathrm{tj}$. namjera stranaka da svoj spor podnesu na odlučivanje arbitražnom sudu i specifičnost predmeta spora koji je dostavljen arbitrima) ili o bilo kojoj drugoj točki koja se prema zahtjevu stranaka ima smatrati ključnom za zaključivanje arbitražnog sporazuma; i (ii) ako je pretpostavka da je sklopljen valjani sporazum, može li se ovaj sporazum tumačiti kao ugovaranje nadležnosti CAS-a.

Iz svega navedenoga, može se zaključiti da je arbitražni ugovor sklopljen ako su stranke uzajamno izjavile suglasnost o svim bitnim elementima ugovora. Sukladno tome, ugovor se mora tumačiti prema pravoj namjeri stranaka ili, ako to nije moguće, prema načelu povjerenja. Nužni sastojci ugovora trebali bi se ispitati nakon razmatranja načela pogodnosti pravnog posla (favor negotii, tj. mjerodavno pravo za posebna pitanja o kojima ovisi valjanost pravnog posla, kao što su poslovna sposobnost stranaka i oblik), prema kojem se arbitražni ugovor tumači na način koji pogoduje njegovoj valjanosti. Ovaj stav potvrđen je upravo u predmetu $C A S$ 2010/O/2129, M. v. C., gdje je vijeće utvrdio CAS ,najprikladnijom institucijom, u slučaju nenadležnosti FIFA-e i bilo kakve indicije o nadležnosti UEFA-e“. Navedeni stav potvrdio je Švicarski federalni sud i u drugim predmetima, kao što je npr. predmet ATF 4A_103/2011 od 20. rujna 2011.55

55 Vidjeti http://www.swissarbitrationdecisions.com/federal-tribunal-reaffirms-its-liberal-approachtowards-the inte. U navedenom predmetu vijeće je zauzelo pravni stav da arbitražna klauzula koja se odnosi na „sve sporove u vezi s ugovorima o licenciji“ na prvi bi pogled bila ograničena samo na tražbine koje proizlaze iz ugovora o licenciji. Međutim, dokle god Svjetska boksačka organizacija (jedna od stranaka u postupku) sadrži odredbe u statutu kojima je propisano da će o svim sporovima odlučivati CAS, dotle je točna široka interpretacija CAS-a da arbitražna klauzula obuhvaća i tražbine u odnosu na dostavljenu opremu, jer ugovor o licenciji nema isključivo karakteristike klasičnog licencnog ugovora, već izražava široki spektar ugovornih odnosa. Navedeno otprilike odgovara i interpretaciji ugovora u hrvatskoj sudskoj praksi, tj. da bez obzira na naziv ugovora, sadržaj je taj koji ugovoru određuje identitet. 


\section{NENADLEŽNOST KAO RAZLOG ZA PONIŠTAJ PRA VORIJEKA}

Nepostojanje i nevaljanost pristanaka na rješavanje sporova pred arbitražnim vijećem CAS-a svakako je osnova za poništaj arbitražnih pravorijeka, sukladno odredbi članka 190 st. 2(b) švicarskog Zakona o međunarodnom privatnom pravu (PILA). Iako su navedene situacije rijetke, postoje slučajevi, posebice u nogometu, gdje je isti spor obuhvaćen odredbama različitih ugovora koji sadrže nekonzistentne odredbe o rješavanju sporova (npr. jednim ugovorom je ugovoreno rješavanje sporova pred redovnim državnim sudovima, dok je drugim ugovorom ugovoreno rješavanje sporova arbitražom). U jednom predmetu, arbitražno vijeće CAS-a oglasilo se nenadležnim po službenoj dužnosti, a da stranke uopće nisu istaknule prigovor nenadležnosti. ${ }^{56} \mathrm{U}$ dosadašnjoj praksi CAS-a, tek je nekoliko poznatih slučajeva u kojima su pravorijeci poništeni zbog nenadležnosti arbitražnog suda za odlučivanje.

\subsection{Sudska praksa Švicarskog federalnog suda o pitanju nenadležnosti}

\section{a) Predmet Busch}

U jednoj stvari, tj. već spomenutom predmetu $B u s c h,{ }^{57}$ njemački hokejaš bio je određen za doping testiranje izvan natjecanja, no istom se odbio podvrgnuti. Hokejaš nije bio sankcioniran, jer u to vrijeme Njemačka hokejaška federacija još uvijek nije usvojila odredbe o sankcijama za takvu vrstu odbijanja, no WADA ${ }^{58}$ je svejedno zatražila od CAS-a da sankcionira sportaša po osnovi „Registracijskog formulara igrača" koji je sadržavao antidopinška pravila Međunarodne hokejaške federacije (IIHF) i koji je bio primjenjiv za prethodno Svjetsko prvenstvo. CAS je prijedlog sankcije usvojio, no Švicarski federalni sud je u konačnici poništio pravorijek CAS-a, uz obrazloženje da „Registracijski formular igrača“ ne predstavlja arbitražni ugovor prema kojem bi ovaj predmet mogao biti riješen pred CAS-om. ${ }^{59}$

\section{b) Predmet $I A A F$}

U drugoj stvari, odlukom od 3. svibnja 2010. Švicarski federalni sud uskratio je nadležnost CAS-u da preispita zakonitost odluke nacionalne atletske federacije prema kojoj je sportaš suspendiran zbog dopinga. Pravila federacije nisu sadržavala arbitražnu klauzulu CAS-a, no CAS je prihvatio nadležnost na temelju pisma Međunarodne amaterske atletske federacije ${ }^{60}$ zastupniku sportaša i ukinuo zabranu.

\footnotetext{
56 Odluka Švicarskog federalnog suda od 5. XI. 2007., broj 4A204/2007.

57 Op. cit. u bilj. 19.

58 Svjetska antidopinška agencija.

59 Op. cit. u bilj. 19.

60 IAAF.
} 
Navedeni pravorijek CAS-a poništen je sukladno članku 190. st. 2. (b) PILA-e, čime je u konačnici potvrđena suspenzija nacionalne atletske federacije. ${ }^{61}$

\section{c) Predmet IIHF v SCB Eishockey AG}

U trećoj stvari, djelomičnom odlukom od 13. rujna 2011., CAS je prihvatio nadležnost za odlučivanje u žalbenom predmetu hokejaškog kluba Berne protiv odluke IIHF-a ${ }^{62}$ o prestanku organiziranja CHF-a,${ }^{63} \mathrm{a} u$ koje natjecanje se hokejaški klub Berne kvalificirao 2009./10. i 2010./11. uslijed rezultata ostvarenih u domaćem prvenstvu. IIHF je osporio odluku CAS-a pred Śvicarskim federalnim sudom, koji je utvrdio da CAS-ova arbitražna klauzula sadržana u CHL-ugovoru između IIHF-a i raznih nacionalnih federacija, ne predstavlja osnovu na koju se može pozivati klub koji se natječe, ali nije stranka CHL-ugovora. ${ }^{64}$

\section{d) Predmet WADA, AFL \& ASADA (opseg odlučivanja)}

U četvrtoj stvari pojavilo se pitanje pravovremenosti podnošenja žalbe CAS-u, te je konačna presuda Švicarskog federalnog suda posljednji korak u dugotrajnom postupku u vezi s programom dodataka sportskoj prehrani kluba australskog nogometa Essendon (dalje: klub). U navedenom postupku žalitelji su bila 34 profesionalna igrača kluba, koji se natječu u AFL-u ${ }^{65}$ i koji je uveo program dodataka za svoje igrače u rujnu 2011. injekcijama koje navodno sadrže zabranjene supstance. Nakon ASADA-ine ${ }^{66}$ inicijalne istrage i postupka AFL-a protiv žalitelja, antidopinški tribunal AFL-a donio je 31. ožujka 2015. odluku da ne postoje dokazi o povredi primjenjivih antidopinških pravila.

Posljedično, WADA je uložila žalbu CAS-u, te je arbitražno vijeće dopustilo miješanje AFL-a i ASADA-e u postupak. Sukladno čl. R57 Zakonika sportske arbitraže, CAS je odlučio provesti cijeli postupak de novo ${ }^{67}$ i razmotriti nove dokaze koje eventualno podnesu stranke.

Pravorijekom od 11. siječnja 2016., arbitražno je vijeće utvrdilo postojanje povrede antidopinških pravila i odredilo tridesetčetvorici igrača dvogodišnje razdoblje nepodobnosti [bavljenja australskim nogometom].

61 Odluka švicarskog federalnog suda 4A_456/2009. od 3.05.2010., u predmetuAthletics South Africa v. Thys

62 Svjetska hokejaška federacija.

63 Međunarodna hokejaška liga prvaka.

64 Odluka švicarskog federalnog suda 4A_627/2011. od 8. III. 2012., u predmetu Međunarodna hokejaška federacija (IIHF) v SCB Eishockey AG.

65 Australska nogometna liga.

66 Australska antidopinška agencija.

67 Hrv. ispočetka. Pojam označava potpunu mogućnost preispitivanja odluka donesenih od (kvazi) sudbena tijela sportskih udruga, koje odluke prema članku R57 Zakonika sportske arbitraže, CAS može (činjenično i pravno) u cijelosti preispitati. Intencija navedenog članka je omogućiti strankama da svoj spor u cijelosti (a ne samo u okviru žalbenih navoda na utvrđenja sportskih tijela) iznesu pred nezavisni arbitražni tribunal, što tijela sportskih udruga koja primarno odlučuju pravima/obvezama/odgovornosti sportaša nisu. 
Potom je uslijedila žalba igrača Švicarskom federalnom sudu, uz zahtjev za poništaj pravorijeka CAS-a zbog nenadležnosti. U suštini, žalitelji su naveli da je zbog de novo principa razmatranja spora, arbitražno vijeće prekoračilo svoju nadležnost odlučivanja, ${ }^{68}$ a podredno i povrijedilo načelo zaštite javnog poretka. ${ }^{69}$ U navedeno vrijeme, antidopinški pravilnik AFL-a iz 2010. bio je na snazi i omogućavao samo ograničeno preispitivanje odluka po žalbi (tj. zbog pogrešne primjene materijalnog prava, bitne povrede odredaba postupka uslijed nejasne i neobrazložene odluke, te očite neravnopravnosti stranaka). Potpuna mogućnost preispitivanja odluka po žalbi bila je moguća tek u Pravilima iz 2015., što nije bilo primjenjivo u spornom razdoblju.

Pozivajući se na opće principe primjenjive na arbitražne klauzule prema švicarskom pravu, švicarski federalni tribunal je ponovio da prigovor nenadležnosti mora biti istaknut prije bilo kakvog očitovanja o meritumu, sukladno načelu dobre vjere. U ovom slučaju, žalitelji su zaista inicijalno prigovorili de novo principu razmatranja spora, ali nisu prigovarali nadležnosti CAS-a nakon što je vijeće odlučilo razmotriti predmet de novo i prihvatiti nove dokaze. Žalitelji su čak i potpisali - bez rezervacija - redoslijed postupanja, sukladno kojem će vijeće CAS-a suditi „u skladu s Pravilnikom sportske arbitraže“. Osim navedenog, žalitelji su u potpunosti iskoristili procesnu ovlast de novo principa, te dostavili vijeću nove dokaze (uključujući nalaze i mišljenja vještaka) i inzistirali na produljenju roka $\mathrm{u}$ vezi s određenim laboratorijskim testiranjima, bez pridržavanja bilo kakvih rezervacija.

Švicarski federalni sud je, komentirajući odnos između procesnih pravila CAS-a i posebnih propisa nacionalnog saveza, istaknuo da članak R57 Pravilnika sportske arbitraže nije predvidio bilo kakve rezervacije koje bi dale pravo prvenstva odredbama nacionalnih saveza, slijedom čega je utvrdio da su žalitelji izgubili pravo na prigovor, te odbio žalbu. ${ }^{70}$ Dodatno, Švicarski federalni sud je utvrdio da je članak R57 CAS Pravilnika o sportskoj arbitraži pravno obvezujuća procesna odredba, posebice u slučajevima vezanima za doping, jer se koristi radi osiguranja poštovanja međunarodnih standarda za borbu protiv dopinga i kao standard za primjenu relevantnih odredbi o antidopingu. Čak i kada bi se stav žalitelja razmatrao kroz prizmu nacionalnih odredbi (koje omogućuju samo usko određene razloge za žalbu) i bez obzira na obvezna procesna pravila CAS-a (koja omogućuju potpuno preispitivanje odluka), arbitražni ugovor i dalje ne bi bio ništetan u cijelosti, već samo djelomično. ${ }^{71}$

Sveukupno, ovo je bitna presuda, u kojoj je zanimljivo primijetiti dvije stvari. Prvo, žalitelji su prigovorili isključivo opsegu arbitražne klauzule, a ne postojanju iste. Drugo, artikuliran je stav da čak i da stranka prigovori nadležnosti u početnom stadiju arbitražnog postupka, njezino naknadno postupanje, a posebice potpisivanje

\footnotetext{
68 prema čl. 190 (2) (b) PILA-e.

69 prema čl. 190 (2) (e) PILA-e.

70 Odluka Švicarskog federalnog suda od 27. rujna 2016., 4A_102/2016, _v. WADA, AFL, ASADA.

71 Ibid.
} 
redoslijeda postupanja (bez rezervacije), onemogućit će stranku u prigovaranju nadležnosti/opsegu preispitivanja odluka, u postupku za poništaj.

\subsection{Odluka o parničnom trošku nakon utvrđenja nenadležnosti}

Dakle, u situacijama gdje federalni sud utvrdi nepostojanje valjanog arbitražnog ugovora, osim poništaja pravorijeka, isti Sud donosi i odluku o meritumu, deklaratornom odlukom o nenadležnosti arbitražnog suda da odlučuje u sporu. U takvim situacijama, postavlja se pitanje može li arbitražni sud svejedno donijeti pravorijek ograničen isključivo na pitanje parničnih troškova. Navedeno je pitanje bitno iz razloga što federalni sud u kontekstu žalbe može samo donijeti odluku o troškovima pred tim sudom, dok ne može donijeti odluku o troškovima arbitražnog postupka. Dio pravnih teoretičara smatra da kada federalni sud poništi odluku arbitražnog suda, taj isti arbitražni sud nema nikakve nadležnosti za daljnje odlučivanje u tome predmetu, dok bi stranka koja je uspjela u postupku pred federalnim sudom, trošak koji joj je nastao u postupku pred arbitražnim sudom morala tražiti u zasebnom postupku pred državnim sudovima. Drugi je stav kako arbitražni sud može odlučivati o trošku arbitražnog postupka, čak i u slučaju kada federalni sud poništi odluku arbitražnog suda zbog nenadležnosti. Slijedom svega navedenog, predlaže se pažljivo sastavljati podneske u postupku pred Švicarskim federalnim sudom, na način da sadrže i prijedlog da se predmet vrati CAS-u na odlučivanje o troškovima postupka. ${ }^{72}$

\section{ZAKLJUČAK}

Za odgovor na pitanje o postojanju potencijalnog problema kod ugovora kojima je za rješavanje sporova ugovorena nadležnost Arbitražnog suda za sport, autor smatra da je ključno sagledati razvoj sudske prakse (CAS-a i Svicarskog federalnog suda) u odnosu na element „dobre vjere“ kod situacija gdje se arbitražne klauzule nalaze u referenci Statuta ili drugog propisa/akta sportskog saveza.

Naime, kod valjanosti referentnih arbitražnih klauzula, ključan je element ,dobre vjere“, odnosno prema sudskoj praksi „referenca treba biti konkretna i precizna, a dokument koji sadrži arbitražnu klauzulu mora biti jasno sastavljen i poznat ugovornim stranama“, iako odredbe članka R27 Zakonika sportske arbitraže nigdje ne propisuju takve rezerve, čime su inače stroga arbitražna pravila relativizirana, te će se od slučaja do slučaja procjenjivati spoznaja sportaša o njihovu postojanju, kao i pristanku na iste, odnosno kako eventualno nepristajanje utječe na opstanak arbitražnog ugovora (makar u dijelu). Dakle, iz čisto formalnih odredbi, nastao je problem pristanka i čitav niz potencijalno negativnih učinaka, premda na prvu izgleda samo kao intencija da se osigura što veća pravna sigurnost stranaka.

72 Lewis and Taylor, op. cit. u bilj. 4., str. 1085. 
Prema praksi Švicarskog federalnog suda, sportaš bi trebao biti svjestan odredbi Pravilnika federacije kad god bude zahtijevao (od iste) odobrenje za sudjelovanje na natjecanju, no nigdje nije navedena kvaliteta te svijesti, odnosno je li dovoljno da sportaš potpiše unaprijed pripremljeni obrazac na kojem je navedena nekakva vrsta opće reference, a sve također u odnosu na pretpostavku Švicarskog federalnog suda „,da sportaš priznaje propise federacije s kojima je upoznat ako se već prijavio toj federaciji za natjecanje ili ishođenje igračke dozvole“. Također, stav je Śvicarskog federalnog suda da nije valjan arbitražni ugovor ako je stranka koja je uvrstila referencu znala ili trebala znati da druga strana ne bi pristala sklopiti ugovor pod navedenim okolnostima, gdje ostaje otvoreno pitanje u kojim to slučajevima bi stranka koja je uvrstila referenciju trebala znati da druga strana ipak ne bi pristala na arbitražno rješavanje potencijalnih sporova.

Osim (sporedne činjenice) što arbitražno sudovanje pred CAS-om poprima još snažniji common law karakter i odmiče se od kontinentalno-europskog pravnog sustava, zakonski ustanovljena mogućnost sklapanja referentnih arbitražnih klauzula sada je uvjetno presumirana, te je doprinos pravnoj nesigurnosti $\mathrm{u}$ kontekstu članka V. Njujorške konvencije iz 1958., kojom je propisano (u toč. 1.) da će ,priznanje i izvršenje odluka biti odbijeni, na zahtjev stranke protiv koje se odluka ističe, jedino ako ta stranka podnese dokaz nadležnoj vlasti u kojoj su traženi priznanje i izvršenje: ... (c) da se odluka odnosi na spor koji nije predviđen u kompromisu ili nije obuhvaćen arbitražnom klauzulom ...", dok je (u toč. 2.) propisano da „Priznanje i izvršenje arbitražne odluke mogu također biti odbijeni ako nadležna vlast u zemlji u kojoj je traženo priznanje ili izvršenje odluke utvrdi: ... (b) da bi priznanje ili izvršenje odluke bilo protivno javnom poretku te zemlje.“, iz čega u konačnici prema mišljenju autora samo ostaje za vidjeti kada će nastati prvi problem u državi gdje će se ovrha po pravorijeku trebati provesti, za neku od činidbi (npr. kondemnatorni nalog na isplatu naknade ili troška arbitražnog postupka) koje nisu isključivo u okviru djelatnosti nacionalnih saveza kojima igrač pripada ili međunarodnih saveza koji organiziraju određeni sportski turnir (pa mogu provesti bilo koji oblik nepodobnosti za natjecanje), a gdje će prema prethodno izloženom stanju, tuženik u svojstvu ovršenika moći iznositi razne prigovore o nedostatku elementa „dobre vjere“ pri sklapanju arbitražnog ugovora, čime bi naplativost tražbine kao ključni element pravorijeka mogla biti dovedena u pitanje, a samim time i cjelokupni „financijski“" segment odluka koje se donose pred Arbitražnim sudom za sport.

CAS će morati posebno oprezno pristupiti ovom problemu, ali i drugima, uzevši u obzir da je nedavnom odlukom Europskog suda za ljudska prava u predmetu Pechstein, s jedne strane konstatirano da CAS ima karakteristike „Vrhovnog suda za svjetski sport“ čime je njegova pozicija dodatno učvršćena, no s druge strane je CAS obvezan postupati potpuno u skladu s načelom pravičnosti koje proizlazi iz članka 6. Europske konvencije, što je u konkretnom slučaju bilo referirano na pitanje javnih suđenja na zahtjev stranaka, no ostaje otvoreno i za daljnja pitanja koja će se (možda) pojaviti. U kontekstu jurisdikcije, osim gore istaknutoga, u radu smo se dotaknuli i patoloških arbitražnih klauzula, kao još jedne ,jurisdikcijske bolne 
točke“, gdje je, prema trenutnoj praksi Švicarskog federalnog suda, na tribunalu da interpretira pitanje pristanka na arbitražu, nevezano za navode stranaka. Autor je (dosta pragmatičnog) stava da bi se u navedenom slučaju trebala primijeniti negativna presumpcija, tj. pretpostavljeno nepostojanje ugovora u slučaju nepotpunih, nejasnih ili kontradiktornih odredbi, čime bi se prevenirala potencijalna neprovedivost arbitražnih pravorijeka.

I konačno, u radu je artikuliran i stav Švicarskog federalnog suda da čak i da stranka prigovori nadležnosti u početnom stadiju arbitražnog postupka, njezino naknadno postupanje, a posebice potpisivanje redoslijeda postupanja (bez rezervacije), onemogućit će stranku u prigovaranju nadležnosti/opsegu preispitivanja odluka u postupku za poništaj, s čime se autor ne slaže, jer to također otvara prostor pravnoj nesigurnosti, odnosno legitimno se može postaviti pitanje koliko je puta potrebno istaknuti prigovor nadležnosti da bi isto bilo pravno relevantno. Autor smatra da je to dovoljno učiniti i jednom, na samom početku postupka jer je odluka o kasnijem sudjelovanju i korištenju pravnih mehanizama u postupku, samo pokušaj zaštite prava i interesa stranke u konkretnom postupku, te postavljanje „temelja“ za kasnije postupke za poništaj arbitražnih pravorijeka ili prigovaranja na provođenje ovršnog postupka, a nikako izraz prihvaćanja nadležnosti arbitražnog suda za odlučivanje u sporu.

\section{POPIS LITERATURE I DRUGIH KORIŠTENIH IZVORA}

\section{Pravna književnost, strani izvori}

1. Laurence Boisson de Chazournes \& Ségolène Couturier, „CAS procedures and their efficiency“, CAS Bulletin, Lausanne 2019/2.

2. Lewis and Taylor, Sport: Law and Practice, treće izdanje, Bloomsbury Professional, 2014.

3. Mavromati \& Reeb, The Code of the Court of Arbitration for Sport, Commentary, Cases and Materials, Wolters Kluwer, 2015.

4. Coccia Massimo, ,The jurisprudence of the Swiss Federal Tribunal on challenges against CAS awards“, CAS Bulletin, 2/2013.

\section{Pravni propisi}

1. Konvencije o priznanju i izvršenju stranih arbitražnih odluka iz 1958.

2. Statut FIFA-e iz 2018.

3. Olimpijska povelja, verzija od 26. VI. 2019.

4. CAS Code, siječanj 2019.

5. Swiss Private international Law Act (PILA).

\section{Sudska praksa}

1. Odluka Europskog suda za ljudska prava, Mutu i Pechstein v. Švicarska od 2. X. 2018. (zahtjevi br. 40575/10 i 67474/10). 
2. Korda v. ITF Ltd (1999.) Independent, Odluka AII ER (D) 337 (CA) od 21. IV. 1999.

3. CAS 99/A/223 International Tennis Federation (ITF) v. Petr Korda, Pravorijek od 31. VIII. 1999.

4. Baumann v IOC, NOC Njemačka i IAAF, CAS OG 2000/006.

5. CAS 2013/A/3263, Pravorijek od 14. III. 2014.

6. CAS 2007/O/1229, Pravorijek od 18. XII. 2007.

7. CAS 2011/O/2588, Pravorijek od 27. II. 2012., u predmetu F. v. K.

8. CAS 2004/A/676, Ismailia SC v. CAF, Pravorijek od 15. XII. 2004.

9. CAS 2005/A/952, A. Cole v. FAPL, Pravorijek od 24. I. 2006.

10. CAS 2008/A/1656, PFC Botev 1912 - Plovdiv AD v. BFU \& Hristov, Privremena mjera od 18. XI. 2008.

11. CAS 2012/A/2688, P. Samarinda, D. Sidoardjo FC, Pelita Jaya FC, L. i E. v. PSSI, Pravorijek od 12. IV. 2012.

12. CAS 2013/A/3199, Rayo Vallecano de Madrid SAD v. RFEF, Pravorijek od 22. X. 2013.

13. CAS 2011/A/2472, Al-Wehda Club v. SAFF, Pravorijek od 12. VIII. 2011.

14. CAS 2007/O/1440, P. v. C., Pravorijek o nadležnosti od 21. X. 2008.

15. CAS 2009/A/1910, Telecom Egypt Club v. EFA, Pravorijek o nadležnosti od 9. IX. 2010.

16. CAS 2013/A/3058, FC Rad v. Nebojša Vignjević, Pravorijek o nadležnosti od 14. VI. 2013.

17. CAS 2011/A/2483, Iraklis Thessaloniki FC v. HFF \& GSL, Pravorijek od 21. XII. 2011.

18. CAS 2006/A/1190 od 28. VI. 2006., WADA v. Pakistan Cricket Board \& Akhtar \& Asif.

19. CAS 2013/A/3236, Pravorijek od 20. veljače 2014.

20. CAS 2007/A/1290, Pravorijek od 4. I. 2008., R. v. IOC.

21. CAS 2007/A/1370 \& 1376, FIFA v. STJD \& CBF\& R. Dodo \& WADA v. STJD \& CBF \& R. Dodo, pravorijek od 11. rujna 2008.

22. CAS 2010/A/2255, René Salomon Olembe Olembe v. Kayserispor Kulubu Dernegli, Pravorijek od 16 rujna 2011.

23. Švicarski federalni sud, Presuda 4A_103/2011 od 20. rujna 2011.

24. Švicarski federalni sud, Presuda 4A_246/2011 od 7. studenog 2011.

25. Švicarski federalni sud, Presuda 4A204/2007 od 5. XI. 2007.

26. Švicarski federalni sud, Presuda4A_456/2009. od 3.05.2010., u predmetu Athletics South Africa v. Thys

27. Švicarski federalni sud, Presuda 4A_627/2011. od 8. III. 2012., u predmetu Međunarodna hokejaška federacija (IIHF) v SCB Eishockey AG.

28. Švicarski federalni sud, Presuda 4A_102/2016, od 27. rujna 2016., _ v. WADA, AFL, ASADA. 
29. Švicarski federalni sud, Presuda 4A_358/2009 od 6. studenog 2009., predmet Busch, kojom je poništen pravorijek CAS 2008/A/1564, WADA protiv F.B. i IIHF, od 23. lipnja 2009.

30. Švicarski federalni sud, Presuda 4P_230/2000 od 7. II. 2001., u predmetu S. Roberts v. FIBA.

\section{JURISDICTIONAL OBJECTIONS IN THE PRACTICE OF THE COURT OF ARBITRATION FOR SPORT}

This paper deals with the various aspects of contracts by which the parties agree on jurisdiction

of the Court of Arbitration for Sport to decide their legal matter, as well as with the various manifestations of arbitration agreements - as prescribed by law; in regards to the CAS legal reasoning and the Swiss federal courts decision on the validity of such contracts in few of its most relevant cases. The purpose of this paper is to highlight the problems that parties may face pro futuro by introducing subjective interpretative categories (by tribunals) as elements in a strictly formal legal act, and to offer certain alternatives to some procedural principles established through the case law of the Swiss Federal Court.

Key words: CAS, jurisprudence, court, sport, sports law 